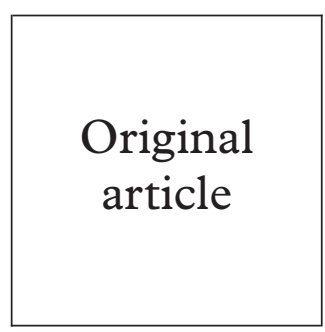

\title{
Knowledge of Chlamydia trachomatis infection in genitourinary medicine clinic attenders
}

\author{
D J Kellock, H Piercy, K E Rogstad
}

\begin{abstract}
Objectives: To determine the level of awareness of genital chlamydial infection, and level of knowledge related to this infection, in genitourinary medicine (GUM) clinic attenders.

Methods: 500 consecutive patients attending a GUM clinic for the first time during a 3 month study period were invited to complete an anonymous self administered questionnaire on aspects of chlamydial infection.

Results: $482(96.4 \%)$ questionnaires were available for analysis (57\% female). 289 (60\%) respondents had heard of Chlamydia trachomatis compared with 472 (98\%) for thrush, 467 (97\%) for HIV/AIDS, and $434(90 \%)$ for gonorrhoea. Subjective knowledge of chlamydia, relative to the other infections, was poor. Overall, the mean chlamydial knowledge score was 0.38 (range 0.01.0). Females scored significantly higher than males $(0.45 v 0.26 ; \mathrm{p}<0.00001)$ and younger females scored significantly higher than older females $(\mathrm{p}=0.001)$. More females had experienced genital chlamydial infection than males $(22.4 \% v 12.1 \%, \mathrm{p}=0.004)$. Those with prior exposure to $C$ trachomatis had higher mean knowledge scores than those without (males $0.55 v 0.25$, $\mathrm{p}<0.00001$; females $0.68 v 0.37, \mathrm{p}<0.00001)$.

Conclusion: Even for a population considered as "high risk" by their attendance at a GUM clinic, there was poor awareness of genital chlamydial infection, and mean knowledge scores were low. Whether increased knowledge was due to successful health education at the time of diagnosis in those with previous infection remains to be determined. In the future, one would hope for increased knowledge scores in those at risk before the acquisition of infection, which may be achieved by national health education programmes for $C$ trachomatis.

(Sex Transm Inf 1999;75:36-40)
\end{abstract}

Keywords: genitourinary medicine clinics; Chlamydia trachomatis

\section{Introduction}

Chlamydia trachomatis is the commonest curable bacterial sexually transmitted infection in the United Kingdom, with over 33000 cases of genital chlamydial infection diagnosed annually in genitourinary medicine (GUM) clinics in England. ${ }^{1}$ Population studies have suggested that this figure equates to only $10 \%$ of prevalent cases, ${ }^{2}$ and that a substantial reservoir of asymptomatic infection remains undetected in those groups perceived as low risk. ${ }^{3}$

In the United Kingdom, the identification of $C$ trachomatis is based on testing those patients who present with symptoms, or who request screening, or by opportunistic screening of asymptomatic at risk individuals. Widespread screening for genital chlamydial infection in other countries has been shown to decrease the incidence of $C$ trachomatis, ${ }^{4}$ pelvic inflammatory disease, ${ }^{5}$ and ectopic pregnancy. ${ }^{6}$

By increasing the public's awareness of $C$ trachomatis, and educating them with regard to this infection, informed individuals might prevent initial exposure by the use of barrier contraception, or attend earlier for screening if they perceive they are at risk of infection. There are limited data in the published literature on the knowledge base of the sexually active population with respect to $C$ trachomatis, with most studies involving work on gonorrhoea, ${ }^{7}$ human papillomavirus, ${ }^{8}$ or $\mathrm{HIV}^{9}$ knowledge.

\section{Objectives}

The aims of the study were:

(1) to determine the level of awareness of genital $C$ trachomatis infection in GUM clinic attenders relative to their awareness of other infections,

(2) to determine the level of knowledge related to genital $C$ trachomatis infection in GUM clinic attenders,

(3) to ascertain the perception of personal risk with reference to the acquisition of genital $C$ trachomatis among GUM clinic attenders.

\section{Methods}

Five hundred consecutive patients attending a department of genitourinary medicine for the first time during a 3 month period (mid April to mid July 1997) were invited to participate in the study. Verbal and written information on the study were provided, verbal consent was obtained, and the patients were requested to complete an anonymous self administered questionnaire. Those who had previously completed a questionnaire during the study period were excluded.

The questionnaire consisted of closed questions and linear analogue rating scales to identify respondents'

- self assessed awareness of 11 genital/sexually acquired infections (namely, gonorrhoea, syphilis, chlamydia, trichomoniasis, thrush, bacterial vaginosis, HIV/AIDS, warts, herpes, hepatitis B, hepatitis C) 
Table 1 Questions to assess the knowledge base of Chlamydia trachomatis in GUM clinic attenders ( $n=482)$

\begin{tabular}{|c|c|c|c|c|}
\hline Question & Correct response & Incorrect response & Don't know & No response \\
\hline 1 Chlamydial infection is caused by bacteria & $39.6 \%$ & $5.4 \%$ & $51.5 \%$ & $3.5 \%$ \\
\hline 2 Chlamydial infection can be caught from toilet seats & $54.8 \%$ & $3.1 \%$ & $39.0 \%$ & $3.1 \%$ \\
\hline 3 Chlamydial infection can be caught in swimming baths & $53.5 \%$ & $1.9 \%$ & $40.0 \%$ & $4.6 \%$ \\
\hline $\begin{array}{l}4 \text { Chlamydial infection can be caught by having sex with } \\
\text { someone who already has the infection }\end{array}$ & $68.3 \%$ & $0.8 \%$ & $27.4 \%$ & $3.5 \%$ \\
\hline $\begin{array}{l}5 \text { Chlamydial infection can be caught by sharing bath } \\
\text { towels with an infected person }\end{array}$ & $38.4 \%$ & $8.1 \%$ & $49.6 \%$ & $3.9 \%$ \\
\hline $\begin{array}{l}6 \text { Chlamydial infection can be avoided by using a } \\
\text { condom during sex }\end{array}$ & $65.1 \%$ & $2.5 \%$ & $28.8 \%$ & $3.5 \%$ \\
\hline 7 Chlamydial infection can be treated with antibiotics & $52.7 \%$ & $2.1 \%$ & $41.5 \%$ & $3.7 \%$ \\
\hline $\begin{array}{l}8 \text { If someone has had a chlamydial infection once they } \\
\text { cannot catch it again }\end{array}$ & $54.8 \%$ & $1.0 \%$ & $40.2 \%$ & $3.9 \%$ \\
\hline $\begin{array}{l}9 \text { If women have chlamydial infection they usually have } \\
\text { symptoms }\end{array}$ & $24.5 \%$ & $22.8 \%$ & $48.3 \%$ & $4.4 \%$ \\
\hline $\begin{array}{l}10 \text { If men have chlamydial infection they usually have } \\
\text { symptoms }\end{array}$ & $24.9 \%$ & $18.0 \%$ & $52.9 \%$ & $4.1 \%$ \\
\hline $\begin{array}{l}11 \text { Chlamydial infection causes a smelly green discharge } \\
\text { in women }\end{array}$ & $14.3 \%$ & $10.2 \%$ & $70.7 \%$ & $4.8 \%$ \\
\hline $\begin{array}{l}\text { 12. Chlamydial infection makes women feel sore and } \\
\text { itchy around the vagina }\end{array}$ & $12.4 \%$ & $20.7 \%$ & $62.4 \%$ & $4.4 \%$ \\
\hline $\begin{array}{l}13 \text { Chlamydial infection can make it painful for women } \\
\text { to pass urine }\end{array}$ & $30.3 \%$ & $7.3 \%$ & $58.7 \%$ & $3.7 \%$ \\
\hline $\begin{array}{l}14 \text { Chlamydial infection can cause a heavy white } \\
\text { discharge in women }\end{array}$ & $24.9 \%$ & $5.8 \%$ & $65.4 \%$ & $3.9 \%$ \\
\hline $\begin{array}{l}15 \text { Chlamydial infection produces ulcers (sores) in the } \\
\text { genital area in women }\end{array}$ & $19.1 \%$ & $7.3 \%$ & $68.7 \%$ & $5.0 \%$ \\
\hline $\begin{array}{l}16 \text { Women can have chlamydial infection without } \\
\text { knowing it }\end{array}$ & $45.2 \%$ & $3.1 \%$ & $47.1 \%$ & $4.6 \%$ \\
\hline $\begin{array}{l}17 \text { Men can have chlamydial infection without knowing } \\
\text { it }\end{array}$ & $38.6 \%$ & $7.7 \%$ & $49.2 \%$ & $4.6 \%$ \\
\hline 18 Chlamydial infection does not need to be treated & $67.2 \%$ & $0.6 \%$ & $27.6 \%$ & $4.6 \%$ \\
\hline $\begin{array}{l}19 \text { Chlamydial infection can cause long term health } \\
\text { problems }\end{array}$ & $41.3 \%$ & $5.6 \%$ & $48.5 \%$ & $4.6 \%$ \\
\hline 20 Chlamydial infections can make women infertile & $42.9 \%$ & $2.9 \%$ & $50.0 \%$ & $4.1 \%$ \\
\hline 21 Chlamydial infection can cause cancer of the cervix & $7.5 \%$ & $13.1 \%$ & $74.9 \%$ & $4.6 \%$ \\
\hline $\begin{array}{l}22 \text { Chlamydial infections can cause ectopic pregnancies } \\
\text { (pregnancy in your tubes) }\end{array}$ & $17.4 \%$ & $5.4 \%$ & $73.0 \%$ & $4.1 \%$ \\
\hline 23 Chlamydial infection can cause fibroids & $7.9 \%$ & $3.7 \%$ & $84.0 \%$ & $4.4 \%$ \\
\hline
\end{tabular}

- knowledge of the acquisition, symptoms, treatment, and sequelae of genital chlamydial infection

- perception of personal risk of acquiring genital chlamydia

- sources of information regarding chlamydia

- previous genital infections.

From the 23 questions relating to chlamydial knowledge (table 1), a mean knowledge score was calculated for each respondent from the number of correct responses (the numerator) over the number of questions attempted (the denominator), giving a value between " 0 " and "1".

Data analysis was carried out using the sPSS and EPI-INFO statistical packages.

\section{Results}

A total of $482(96.4 \%)$ questionnaires were completed: $206(42.7 \%)$ from men and 259 $(53.7 \%)$ from women. Sex was not stated on 17 (3.5\%) replies.

The mean age of respondents was 27.5 years: males 29.5 (SD 8.5, range 15-59) years, females 25.8 (8.2, 14-55) years. The male population was significantly older than the

Table 2 Sex distribution of previous genital infections

\begin{tabular}{lllllll}
\hline Infection & Sex & $\begin{array}{l}\text { Total } \\
\text { responses }\end{array}$ & $\begin{array}{l}\text { Positive } \\
\text { responses }\end{array}$ & $\%$ & p Value & Odds ratio (CI) \\
\hline Chlamydia & Males & 150 & 25 & 16.7 & 0.004 & $0.48(0.28-0.82)$ \\
& Females & 191 & 58 & 30.4 & & \\
Thrush & Males & 164 & 64 & 39.0 & $<0.001$ & $0.17(0.11-0.26)$ \\
\multirow{2}{*}{ Bacterial vaginosis } & Females & 237 & 187 & 78.9 & & \\
& Males & 143 & 1 & 0.7 & 0.0005 & $0.06(0.00-0.42)$ \\
& Females & 172 & 17 & 9.9 & & \\
\hline
\end{tabular}

female population (Student's $t$ test: $\mathrm{p}=0.000003$ ), with $55.8 \%$ of men, and $74.5 \%$ of women under 30 years of age.

PREVIOUS GENITAL INFECTIONS

The commonest infections previously experienced by females $(n=259)$ were thrush $(72.2 \%)$, genital warts $(30.1 \%)$, and chlamydia $(22.4 \%)$, and by males $(n=206), 31.1 \%, 33.0 \%$, and $12.1 \%$ respectively. Significantly more females than males admitted to infections with chlamydia, thrush, and bacterial vaginosis than with the other infections ( $\chi^{2}$ analysis, table 2$)$.

Age/sex analysis showed that there was a trend for increased infection with chlamydia with younger age in females (contingency table: $p=0.039$ ), but there were no age trends seen with the other genital infections, nor within the male age group analysis. Females aged $<20$ years reported significantly more chlamydial infection than males of the equivalent age (Fisher's exact test: $\mathrm{p}=0.002$ ).

\section{AWARENESS OF GENITAL/SEXUALLY ACQUIRED} INFECTIONS

Overall $(n=482)$, the three most heard of infections were thrush (97.9\%), HIV/AIDS $(96.9 \%)$, and gonorrhoea $(90.0 \%)$. The three least heard of infections were trichomoniasis $(13.7 \%)$, bacterial vaginosis $(20.1 \%)$, and chlamydia $(60.0 \%)$.

Significantly more females were aware of chlamydia, trichomonas, bacterial vaginosis, warts, and herpes than males, but they were less aware of syphilis and hepatitis $\mathrm{C}\left(\chi^{2}\right.$ analysis: table 3$)$. No statistical differences were seen 
between sex and awareness of the other infections.

When breakdown by age/sex is undertaken, significantly more females aged $<20$ years had heard of genital herpes and genital warts; more females aged 20-29 years had heard of chlamydia, bacterial vaginosis, and genital herpes; and more females aged 30-39 years had heard of trichomoniasis than males of the equivalent age. More males aged 20-29 years were aware of hepatitis $C$ than females of the equivalent age (table 3 ).

The awareness of the classic venereal diseases-namely, gonorrhoea, syphilis, and trichomoniasis, increased with age (contingency tables: $p=0.0016, p=0.012$, and $\mathrm{p}=0.0017$ respectively).

Of the 11 infections, both male and female respondents claimed to know most about HIV/ AIDS, thrush, and genital warts. Self assessed knowledge levels on $C$ trachomatis ranked fifth in females and ninth in males.

KNOWLEDGE OF GENITAL CHLAMYDIAL

INFECTION AND PERCEPTION OF RISK

Of the 482 questionnaires returned, 405 $(84.0 \%)$ respondents answered all the questions relating to chlamydial knowledge, and 11 $(2.3 \%)$ answered none. Of the 471 respondents attempting questions from this section of the questionnaire, the mean number of questions answered was 22 , with a mode of 23 . There was no significant difference in response rate with regard to sex.

Of the 460 respondents stating sex who answered any of the chlamydial knowledge questions, $54(26.3 \%)$ males and $130(51.0 \%)$ females achieved a mean knowledge score of over 0.5 , although none attained a perfect score; $151(73.7 \%)$ male and $125(49.0 \%)$ female scored 0.5 or less, of which $64(31.2 \%)$ males and $33(12.9 \%)$ females scored zero.

The overall mean knowledge score was 0.38 (SD 0.28, range 0.0-0.91), with significantly higher scores achieved by females (females 0.45 (SD 0.27) $v$ males 0.29 (SD 0.26): Student's $t$ test: $\mathrm{p}<0.00001)$. This sex difference occurred in the younger age groups, with women aged $<20$ and 20-29 years achieving significantly higher scores than males of the equivalent age (Student's $t$ test: $\mathrm{p}=0.00048$ and $\mathrm{p}<0.00001$ respectively). There was no sex difference between older respondents.

Women aged $<20$ and 20-29 performed significantly better than older women (aged 30-39 years) (Student's $t$ test: $\mathrm{p}=0.0012$ and $p=0.001$ respectively). Linear regression analysis of mean knowledge score and age was also significant $(p=0.0005)$ whereby:

calculated mean knowledge score $=0.64-$ $(0.007 \times$ respondent's age in years $)$

There were no significant differences between the age groups within the male cohort following analysis by either linear regression or $t$ test.

A previous diagnosis of genital chlamydial infection was associated with a significantly higher mean knowledge score (males $0.55 v$ $0.25, \mathrm{p}<0.00001$; females $0.68 v 0.37$, $\mathrm{p}<0.00001$ ), with females again attaining higher mean scores than males: 0.68 (SD 0.14) $v 0.55$ (SD 0.18).

With regard to perception of personal risk of acquiring genital chlamydial infection, 230 $(47.7 \%)$ respondents did not know whether or not they were at risk. Only $91(18.9 \%)$ felt that they were at risk of chlamydia, while 104 $(21.6 \%)$ felt that they were not at risk of the infection. There was no significant relation to sexual intercourse, condom use, or number of previous partners.

In females, there was a lower perception of personal risk of genital chlamydia acquisition with increasing age (contingency table: $\mathrm{p}=0.011$ ).

The commonest location reported by respondents as being a source of information about chlamydia were GUM clinics $(29.5 \%)$,

Table 3 Sex distribution of genital/sexually acquired infections awareness

\begin{tabular}{|c|c|c|c|c|c|c|}
\hline Awareness & Sex/age & Total responses & $\begin{array}{l}\text { Positive } \\
\text { responses }\end{array}$ & $\%$ & $p$ Value & Odds ratio $(C I)$ \\
\hline \multirow{2}{*}{ Syphilis } & Males & 201 & 196 & 97.5 & 0.0022 & $4.17(1.51-14.29)$ \\
\hline & Females & 239 & 216 & 90.4 & & \\
\hline \multirow[t]{2}{*}{ Chlamydia } & Males & 168 & 105 & 62.5 & 0.0015 & $0.49(0.31-0.78)$ \\
\hline & Females & 228 & 176 & 77.2 & & \\
\hline \multirow[t]{2}{*}{ Trichomonas } & Males & 146 & 15 & 10.3 & 0.0015 & $0.37(0.19-0.72)$ \\
\hline & Females & 200 & 47 & 23.5 & & \\
\hline \multirow{2}{*}{ Bacterial vaginosis } & Males & 141 & 25 & 17.7 & 0.0007 & $0.41(0.23-0.71)$ \\
\hline & Females & 198 & 68 & 34.3 & & \\
\hline \multirow[t]{2}{*}{ Genital warts } & Males & 193 & 176 & 91.2 & 0.0029 & $0.26(0.08-0.70)$ \\
\hline & Females & 247 & 241 & 97.6 & & \\
\hline \multirow[t]{2}{*}{ Genital herpes } & Males & 185 & 158 & 85.4 & 0.03 & $0.51(0.26-0.99)$ \\
\hline & Females & 238 & 219 & 92.0 & & \\
\hline \multirow{2}{*}{ Hepatitis C } & Males & 180 & 155 & 86.1 & 0.0013 & $2.29(1.34-4.01)$ \\
\hline & Females & 226 & 165 & 73.0 & & \\
\hline \multirow[t]{2}{*}{ Chlamydia } & Males/20-29 & 83 & 52 & 62.7 & 0.022 & $2.06(1.06-4.04)$ \\
\hline & Females/20-29 & 116 & 90 & 77.6 & & \\
\hline \multirow[t]{2}{*}{ Trichomonas } & Males/30-39 & 41 & 3 & 7.3 & 0.001 & $8.67(1.98-51.46)$ \\
\hline & Females/30-39 & 32 & 13 & 40.6 & & \\
\hline \multirow[t]{2}{*}{ Bacterial vaginosis } & Males/20-29 & 73 & 11 & 15.1 & 0.005 & $2.86(1.24-6.74)$ \\
\hline & Females/20-29 & 107 & 36 & 33.6 & & \\
\hline \multirow{2}{*}{ Genital warts } & Males $/<20$ & 19 & 15 & 78.9 & 0.009 & $16.8(1.46-839)$ \\
\hline & Females/<20 & 64 & 63 & 98.4 & & \\
\hline \multirow[t]{2}{*}{ Genital herpes } & Males/ $<20$ & 18 & 13 & 72.2 & 0.027 & $5.38(0.98-30.37)$ \\
\hline & Females $/<20$ & 60 & 56 & 93.3 & & \\
\hline \multirow[t]{2}{*}{ Genital herpes } & Males/20-29 & 89 & 72 & 80.9 & 0.022 & $2.6(1.05-6.70)$ \\
\hline & Females/20-29 & 120 & 110 & 91.7 & & \\
\hline \multirow[t]{2}{*}{ Hepatitis C } & Males/20-29 & 88 & 79 & 89.8 & 0.003 & $0.31(0.12-0.72)$ \\
\hline & Females/20-29 & 115 & 84 & 73.0 & & \\
\hline
\end{tabular}


Table 4 Sex distribution of source of information regarding chlamydia

\begin{tabular}{lllllll}
\hline Source of information & Sex & $\begin{array}{l}\text { Total } \\
\text { responses }\end{array}$ & $\begin{array}{l}\text { Positive } \\
\text { responses }\end{array}$ & $\%$ & p Value & Odds ratio (CI) \\
\hline Magazines & Males & 90 & 36 & 40.0 & 0.0011 & $0.41(0.23-0.73$ \\
& Females & 149 & 92 & 61.7 & & \\
Family planning & Males & 76 & 11 & 14.5 & 0.0016 & $0.32(0.14-0.69)$ \\
$\quad$ clinics & Females & 126 & 44 & 34.9 & & \\
Young persons & Males & 71 & 0 & 0.0 & 0.02 & $0.00(0.0-0.88)$ \\
$\quad$ clinics & Females & 110 & 8 & 7.3 & & \\
\hline
\end{tabular}

magazines/books $(27.2 \%)$, and friends/family $(22.2 \%)$, although magazines/books, family planning clinics, and young persons clinics were reported by significantly more females than males ( $\chi^{2}$ analysis: table 4$)$. No statistical differences were seen between sex and the other sources of information.

Overall, significantly higher mean knowledge scores were seen in those who received their information from GUM clinics (Student's $t$ test: $p<0.000001$ ), family planning clinic (Student's $t$ test: $\mathrm{p}=0.0001$ ), young persons clinic (Student's $t$ test: $\mathrm{p}=0.038$ ), and magazines/ books (Student's $t$ test: $\mathrm{p}<0.0001$ ) than for those who did not.

\section{Discussion}

Genitourinary medicine clinic attenders are a highly selected population as only $8.3 \%$ men and $5.6 \%$ women report visiting an STD clinic in their lifetime, and less than $1 \%$ will have attended a clinic within the previous 12 months. ${ }^{10}$ Bias may have arisen in those agreeing to complete the questionnaire, and data on non-responders are not available. The reliability and accuracy of self reported data beset all investigations into aspects of human behaviour. Our study incorporated a number of methods, described elsewhere, ${ }^{11}$ designed to increase respondents' willingness to report sensitive information, but to minimise their reporting error. These methods involved the use of an established healthcare setting (GUM clinic), verbal/written information to enhance respondent certainty of confidentiality, and a self administered questionnaire to avoid the influence of an interviewer, although this may result in reduced understanding or misinterpretation by the respondent.

Despite its high prevalence in those who are sexually active, the low awareness of genital chlamydial infection ( $60 \%)$ is of concern. The awareness of $C$ trachomatis in our population is disproportionate to its prevalence when compared with HIV/AIDS and gonorrhoea. It has been suggested that the high profile of HIV (from both the media and healthcare providers) has overshadowed the important issues of other STDs. ${ }^{12}$

As might be anticipated, an increased awareness of the "classic" venereal diseases (gonorrhoea, syphilis, and trichomoniasis) was seen with increasing age. The increased awareness of chlamydia, warts, and herpes in young women compared with the equivalent aged men requires investigation. It may be accounted for by the fact that most young women have older partners, and could be introduced to STDs at an earlier age. ${ }^{10}$ This is supported by the lower age of peak incidence of infections in women for chlamydia ${ }^{1}$ (20-24 years), warts, and herpes.

The level of knowledge of genital chlamydial infection among GUM attenders was poor, even though our cohort of respondents represents a highly selected at risk population, and responders may have agreed to complete the questionnaire because they felt that they possessed knowledge. The knowledge base for genital chlamydial infection in the general population may be lower, and this is supported by similar work in family planning clinic attenders which demonstrated lower mean knowledge scores with an identical questionnaire (H Piercy, personal communication).

Mean knowledge scores were found to be higher in younger females than older females emphasising the need not to ignore older age groups when providing STD education, since events later in life, such as separation and divorce, may lead to new risk behaviours ${ }^{13}$ and STD acquisition. ${ }^{14}$

In this study, a large proportion of respondents did not know whether or not they were at risk of acquiring genital chlamydial infection; the reasons for this require further investigation.

Ideally, one would aim for increased knowledge in those at risk of genital chlamydia before the acquisition of infection, and equally in males and females, enabling informed choice on the part of the individual, allowing appropriate measures to be taken to avoid infection. However, although lack of knowledge is associated with risk behaviour, increased knowledge does not necessarily equate to risk reduction. Behavioural intervention has been shown to increase condom usage in at risk female adolescents, but this was inconsistent, and the rates for reinfection with $C$ trachomatis were not significantly different from the control group. ${ }^{15}$

The knowledge of risk factors for HIV/AIDS acquisition may be detrimental to an individual's perception of personal risk for chlamydia since patients may reassure themselves that they are not in a high risk group and may consequently perform unsafe sexual intercourse. These cognitive errors, which are linked to social comparisons, were described by Festinger $^{16}$ before the advent of HIV. Even when patients correctly identify their risk of STD acquisition, the path to practising safer sex is multifactorial, and needs to address the patients' cultural and social beliefs. ${ }^{17}$

The cost benefit and cost effectiveness of screening for chlamydial infection have been demonstrated many times ${ }^{18} 19$ and the Expert Advisory Group on Chlamydia trachomatis has recommended a national screening programme, ${ }^{20}$ but successful uptake of such a programme would require greater public awareness and knowledge of the condition.

This study supports the need for a health education strategy/primary prevention programme. Suitable vectors for conveying such information/messages may include magazines, TV/radio, and newspapers. ${ }^{21}$ Story lines in television soaps in the United Kingdom (for example, Channel Four Brookside drama: transmission date 5 July 1997) have raised 
issues of STDs/contact tracing following unprotected sexual intercourse, but a coordinated public health education campaign must be undertaken.

Funding: North Derbyshire Community Trust. Conflict of interest: none.

Individual contributions from authors not available.

1 Simms I, Hughes G, Swan AV, et al. New cases seen a genitourinary medicine clinics: England 1996. Commun Dis Rep CDR Suppl 1998;8:S1-11.

2 Renton A, Taylor-Robinson D. The need for an assessment of health technology for screening for Chlamydia trachomatis in the population. National Health Service Executive.

3 Simms I, Catchpole $M$, Brugha R, et al. Epidemiology of genital Chlamydia trachomatis in England and Wales. Genitourin Med 1997;73:122-6.

4 Herrmann BF, Johansson AB, Mårdh P-A. A retrospective study of efforts to diagnose infections by Chlamydia trachostudy of efforts to diagnose infections by Chlamydia tracho-

5 Scholes D, Stergachis A, Heidrich FE, et al. Prevention of pelvic inflammatory disease by screening for cervical chlamydial infection. N Engl F Med 1996:334:1362-6.

6 Egger M, Herrmann B, Low N. Chlamydia control in Uppsala, Sweden is associated with a fall in ectopic pregnancies. Abstract O258, International Congress of Sexually Transmitted Diseases. Seville, Spain, October 1997.

7 Biro FM, Rosenthal SL, Stanberry LR. Knowledge of gonorrhoea in adolescent females with a history of STD. Clin Pediatr 1994;33:601-5.

8 Vail-Smith K, White DM. Risk level, knowledge, and preventive behavior for human papillomaviruses among sexually active college women. 7 Am Coll Health 1992;40:227-30.

9 Hinkle YA, Johnson EH, Gilbert D, et al. African-American women who always use condoms: attitudes, knowledge about AIDS and sexual behaviour. $\mathcal{F}$ Am Med Womens Assoc 1992;47:230-7.

10 Wellings K, Field J, Johnson AM, et al. Sexual behaviour in Britain: the national survey of sexual attitudes and lifestyles. London: Penguin, 1994.

11 Catania JA, Gibson DR, Chitwood DD, et al. Methodological problems in AIDS behavioural research: influences on measurement error and participation bias in studies of sexual behaviour. Psychol Bull 1990;108:339-62.

12 Wyn J. Young women and sexually transmitted diseases: the issues for public health. Aust f Public Health 1994;18:32-9.

13 Marion LN, Cox CL. Condom use and fertility among divorced and separated women. Nurs Res 1996;45:110-15.

14 Rogstad KE, Bignell CJ. Age is no bar to sexually acquired infection. Age and Ageing 1991;20:377-8.

15 Orr DP, Langefeld CD, Katz BP, et al. Behavioral intervention to increase condom use among high-risk female adolescents. F Pediatr 1996;128:288-95.

16 Festinger L. A theory of social comparison. Hum Relation 1954;14:48-64.

17 Drobniewski F. Sex and the nation's health. F Roy Soc Health 1993;113:206-8.

18 Marrazzo JM, Celum CL, Hillis SD, et al. Performance and cost effectiveness of selective screening criteria for Chlamydia trachomatis infection in women: implications for a national chlamydia control strategy. Sex Transm Dis 1997;24:131-41.

19 Genç M, Mårdh P-A. A cost-effectiveness analysis of screening and treatment for Chlamydia trachomatis infection in asymptomatic women. Ann Intern Med infection in $1996 ; 124: 1-7$.

20 Chief Medical Officer's Expert Advisory Group. Chlamydia trachomatis. London: Department of Health, 1998.

21 Anonymous. Sexual risk behaviours of STD clinic patients before and after Earvin "Magic" Johnson's HIV-infection announcement-Maryland, 1991-1992. MMWR 1993;42: $45-8$. 